\title{
Enhancing the Growth and Yield of Lettuce (Lactuca sativa L.) in Hydroponic System Using Magnetized Irrigation Water
}

\author{
Shirly 0. Agcaoili \\ Cagayan State University \\ shirly_agcaoili@yahoo.com
}

\section{Abstract}

The application of magnetic technology to agricultural productions is considered new breakthroughs to the enhancement of food production. However, studies about its application on the hydroponic system of production on high valued crops are limited. Hence, the present study assessed the effect of magnetically-treated water on the growth and yield parameters of lettuce in hydroponic system. Magnetic device with different number of permanent magnets was used to magnetize irrigation water in the hydroponic system. Uniform and healthy seedlings are transplanted and arranged completely randomized design. Magnetically treated water enhanced the growth and yield parameters of lettuce such as weekly height, leaf area, fresh weight, and root length. The height, leaf area, fresh weight, and root length increased up to $44.30 \%, 199.93 \%, 50.72 \%$, and $37.00 \%$, respectively vs. the control. Results revealed that magnetic treatment for water in hydroponic system has potentials to increase the growth of lettuce and consequently its yield.

Keywords: agriculture, magnetized water, irrigation, growth, lettuce, hydroponic system

\subsection{Introduction}

In the recent years, concerns on food security have grown accompanied by abrupt increase in food price focusing attention on increasing food demand and in what way this will be addressed (Linehan, Thorpe, Andrews, Kim, \& Beaini, 2012). As projected by the Food and Agriculture Organization of the United Nations (2009), the global population by the year 2050 would demand an estimation of more than 70 percent greater food demand than what is produced today (Linehan et al., 2012). All at once, it is projected that fifty percent $(50 \%)$ of the land fit for growing crops around worldwide will be unworkable for crop production (United Nations,
2017). Accordingly, productions of food have to be increased by $110 \%$ to address high demand (Gashgari, Alharbi, Mughrbil, Jan, \& Glolam, 2018). The Philippine government, along with other nations, adopted the 2030 Agenda for Sustainable Development in 2015 with a common goal of ending hunger, achieving food security, improving nutrition and promoting sustainable agriculture (Briones, Antonio, Habito, Porio, \& Songco, 2017).

Because of the growing population, specifically in the Philippines, it is vital to increase the production of crops. Besides, area of cultivated land is decreasing, and portion of it is being utilized to construct infrastructures for the growing 
population. Hence, the challenge is to produce more food with less soil and water. Furthermore, natural disasters exacerbate this situation and unrestricted application of chemicals for crop growing purposes caused the decrease in the fertility and quality of soil (Barman, Hasan, Islam, \& Bauu, 2016) resulting to water scarcity and low yield. The growing need for food in the Philippines puts pressure in land use, forest degradation, and natural resources. This destruction attributes to food production (Gabriel\& Mangahas, 2017). To sustain human needs, the development of new food production technology is essential (Pascual, Lorenzo, \& Gabriel, 2018) and other farming methods for food production should be used to prevent food crisis in the coming years (Gashgari et al., 2018). Food productions could be increased in many folds through applications of technological interventions (Agrawal \& Jacob, 2010). Thus, developing new approaches to decrease consumption of water and soil for crop production is of significant importance. These made the researchers to develop an approach such as soil-less cultivation systems, commonly known as hydroponic, and the application of magnetic water in agriculture.

Hydroponics is a culture technique in which plants grow in a soil-less media but use a liquid or a water solution. Hydroponics is a viable method of producing different kinds of vegetables (lettuce, tomatoes, cucumbers, and bell peppers, straw berries, honeydew melons, celery, Mediterranean and Asian herbs and Asian greens) along with ornamental plants, and foliage plants (Dunn, 2013; Sace \& Estigoy, 2015). A great number of crops or vegetables and plants can be grown through hydroponic culture system. The quality of produce, palatability and nutritive value of the end products are generally higher when compared with the usual soil-based farming or cultivation (Barman et al., 2016). The yields of crops grown with hydroponic system are significantly higher than the crops grown with the soil (Sace \& Natividad, Jr., 2015). This cultivation technique is sustainable because it is cost-efficient, clean and eco-friendly. In addition, it is widely accepted all over the world, regardless whether developed or developing countries. Reviews of studies conducted related to hydroponics by Alatore-Cobos et al. (2014); Ferguson, Saliga III and Omay (2014); Pascual et al. (2018); Gashgari et al. (2018); Sardare and Admane (2013); and Sace \& Estigoy, (2015) showed that the technology could increase crop productivity and is promising to meet increasing food demand with scarce water resource and decreasing arable land for food production. Further, sensory evaluation for hydroponically grown lettuce is comparable with conventionally grown lettuce (Murphy, Zhang, Nakamura, \& Omaye, 2011). In the Philippines, despite the problems caused by high temperature and low relative humidity, planting lettuce in a re-circulating hydroponic system is still profitable as manifested by the yield of crops grown in hydroponics system to be three to four times higher than crops grown with soil (Sace \& Natividad, Jr., 2015).

Moreover, magnetic water treatment (MWT) techniques have shown potential as a promising technology in different areas, especially agriculture (Ali \& Samaneh, 2017). The application of the magnetized water technology is regarded as a promising innovative technique to enhance crop water-use efficiency and productivity. The utilization of magnetized water would enable great and more quantity and qualitative agricultural production (Hozayn \& Amir Mohamed Saeed Abdul Qados, 2014). Magnetized water can be obtained by way of passing water completely through a strong permanent magnet mounted in or on a feed conduit pipeline (Mostafazadeh-Fard, Khoshravesh, Mousavi, \& Kiani, 2011). Literatures explained that the structural arrays of water would be modified 
when it passes through a magnetic field resulting in the increasing intercellular movement (Scaloppi, 2008). Magnetic treatment changes hydrogen bonding and increased mobility of ions in water solution and thus resulting to reduction in EC, TDS and increase $\mathrm{pH}$ of solutions (Surendran, Sandeep, \& Joseph, 2016). This permits the restoration of a structure of natural and enhanced water in its capability to disband and transport minerals resulting to more nutrients absorbed in the water (Hachicha, Kahlaoui, Khamassi, N. Misle, \& Jouzdan, 2018; Grewal \& Maheshwari, 2011; Mohamed \& Ebead, 2013; Eitken \& Turan, 2004). This process may result in higher nutrient uptake, increasing the physiological processes in crop production (Scaloppi, 2008). Other researchers quoted changes in physical and chemical properties of water such as hydrogen bonding, conductivity, polarity, refractive index, surface tension, $\mathrm{pH}$ and solubility of salts when water is exposed to magnetic field (Chang \& Weng, 2008). These changes might activate the hormones and enzymes faster during growth process which may result in an improved mobilization and transportation of nutrients and bring out biological activity in plants and consequently influence plants resulting to an improved growth and yield (Maheshwari \& Grewal, 2009; Surendran et al., 2016). Various studies have claimed the beneficial effects of magnetic water in many farming situations. According to the study conducted by Hozayn et al. (2010), the yield of beans, mung bean, and groundnut increased between $11-47 \%$ when irrigated with magnetized water. Improvements of germination, plant growth, flower and a $26.67 \%$ increase in fruit yield of banana (Patil, 2014), enhanced seedling lengths, fresh and dry weights, and chlorophyll content of turnip (Haq et al. 2016) when irrigated with magnetized water. Crop growth and yield parameters of cowpea brinjal have improved when using magnetized water (Surendran et al., 2016).
Root growth of different plant species is influenced by magnetically treated water (Turker, Temerci, Battal, \& Erez, 2017). Hozayn, Abd El Monem, Abd El-Fatah Elwia, and El-Shatar (2014) reported that application of magnetized water could lead to better crop yield and water productivity of different crops like wheat, Faba bean, chickpea, lentil, canola and flax. An increase in the foliate area of lettuce compared to plants grown in the hydroponic system was observed when the electric field is applied (Castañeda, Patiño,M., Patiño, J., Aleman, $\&$ Torres, 2016). Significant positive effect of the application of the magnetic technology is revealed in different crop growth parameters (Selim\& ElNady, 2011; Dagoberto, Angel, \& Lilita, 2002; Moon\& Chung, 2000; Socorro \& Carbonell, 2002; Pittman, 1977). Literature indicates that there are feasibly positive effects of magnetic field treatment of water on plant growth, yield and other related parameters.

Previous studies reported the potential of the two (2) technologies (hydroponic system technology and magnetic water technology) separately as a technological intervention in increasing food production for different crops in many folds. Shukla, Wagh, Vaishamapayan, Gaopande, and Vishnoi (2016), conducted a laboratory scale experiment in determining the effects of magnetic field in wheatgrass grown in hydroponic system using permanent magnets (500 Gauss) positioned directly under the roots of the wheatgrass. Castañeda et al., (2016), conducted an experiment on the response of lettuce grown in hydroponic system as affected by electric field on a laboratory scale. However, this method of magnetization is not for long term as it is affected by the availability of electricity, number of turns in the coil, and current density (Hilal, M.H. \& Hilal, M.M., 2000; Majid, 2009). This presents that there are limited studies reported on the result of utilizing magnetically treated water on crops grown in the 
hydroponic system, specially using high valued crops. The present study evaluated the growth and yield response of lettuce grown in a hydroponic system of production under field conditions, as affected by magnetically treated irrigation water using permanent magnets.

\subsection{Methods}

\section{Preparation of the Nutrient Solution}

The nutrient solution was prepared using nineteen litres of water. The three types of fertilizer (master blend 4-18-38; calcium nitrate and magnesium sulfate) were diluted separately in a three (3) one-litre capacity containers according to manufacturer's recommendation. After diluting each fertilizer in a separate container, it was thoroughly mixed in the nineteen litres of water initially prepared.

\section{Magnetic Field Simulator}

The magnetization was done using a permanent magnetic device as shown in figure 1 . There were two types of magnetic devices used separately to treat water solution. The magnetic devices consisted of identical magnets but of different number of permanent magnets. The first magnetic device consisted of four (4) permanent magnets, while the second magnetic device consisted of six (6) permanent magnets. A 46$\mathrm{cm}$ long PVC pipe of $1.27 \mathrm{~cm}$ in diameter passed through the magnetic devices. The submersible pump allows the water solution to circulate within the system, causing the water solution to pass through the magnetic field many times. The water was treated magnetically using the two magnetic devices and denoted as $T_{1}$ (4 magnets) and $T_{2}$ (6 magnets), whereas T0 (untreated water) as the control. The schematic diagram of the magnetization process used in the study is shown in figure 2.

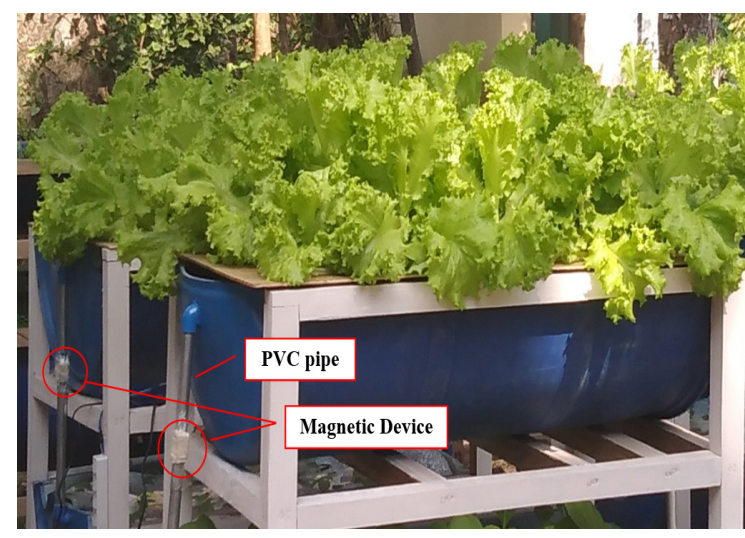

Figure 1. Actual set-up of the experiment

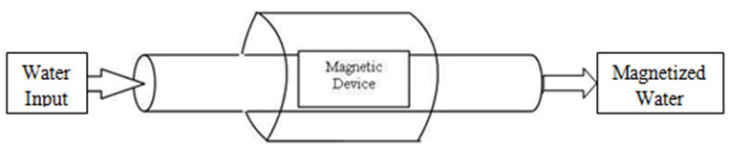

Figure 2. The schematic diagram of the magnetization process used in the study

\section{Agronomic Practices and Sowing}

The study secured lettuce (Lactuca sativa L.) seeds from an agricultural supply outlet. Before sowing, the seeds were evaluated manually for any defects that may cause low germination. Seed selection discarded defective seeds and the good seeds are sown in seedling trays (50\% garden soil and $50 \%$ vermin compost). Two weeks after sowing, transplanting was done using the planting media. The planting media used in this study to hold the newly transplanted plants was polyurethane foam placed inside a Styrofoam cup, is shown in figure 3a. After transplanting, the Styrofoam cups are positioned in the holes provided in a piece of plywood. The plywood was used to hold the Styrofoam cups in position on top of the drum container as shown in figure $3 \mathrm{~b}$. The base 
of the Styrofoam cups (punched with a hole) was partially submerged to the water solution inside the drum to facilitate the absorption of nutrients by the roots. The research experiment was laid out in Completely Randomize Design (CRD) with three treatments including the control in triplicate.
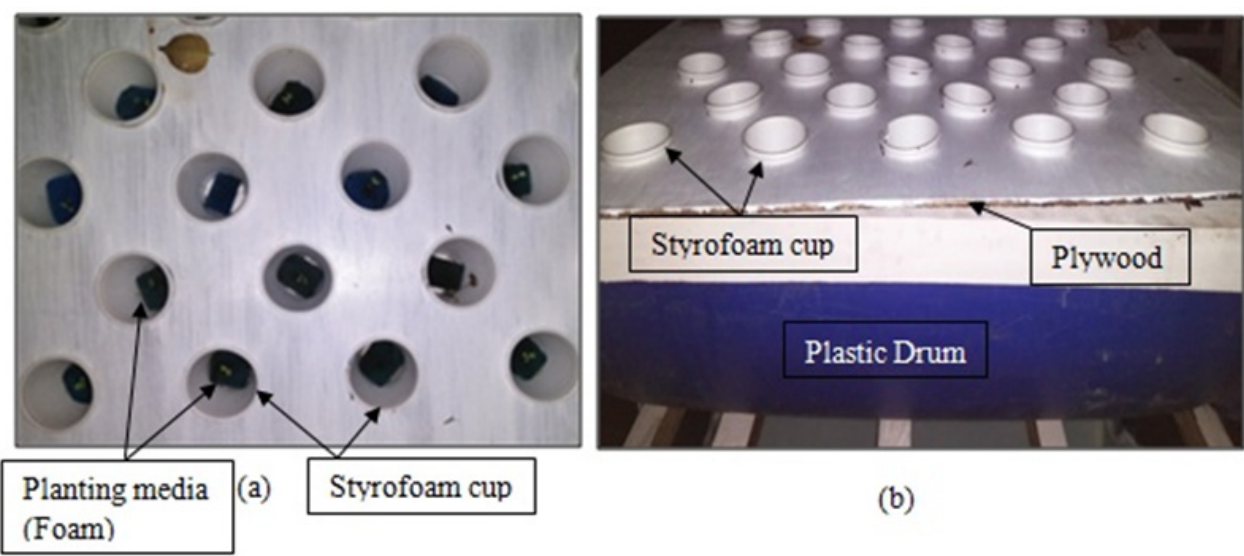

(b)

Figure 3. A photograph showing the (a) planting media inside the styrofoam cups used in the study and the (b) position of the styrofoam cups in the plywood on top of the drum spaced $20 \mathrm{~cm}$ by $20 \mathrm{~cm}$

\section{Response Measurement}

After transplanting, the heights of the newly transplanted seedlings were measured and statistically analyzed to ensure the uniformity of heights of the test crop before treatment application. Response measurements include the weekly height of the plants starting from the day after transplanting until harvesting, the leaf area $(\mathrm{cm} 2)$ of the plants, the fresh weight $(\mathrm{g})$ of plants, and the length of roots at harvest. Using a ruler, the heights of plants were measured from the base of the plant to the tip of the longest leaf. Leaves of the sample plants were taken and measured using standard methods of measuring leaves of plants of irregular shapes. The fresh weight was taken by weighing the plants using a digital weighing scale. The root length $(\mathrm{cm})$ of the plant was taken by measuring the root from the neck of the root to the tip and shoot from base to tip by using a ruler (Iqbal et al., 2013).

\section{Statistical Analysis}

The analysis of variance (ANOVA) for each parameter was calculated using the embedded statistical analysis in office excel 2007. The least significant difference (LSD) test at a $1 \%$ level of probability was applied to test the differences among means.

\subsection{Results and Discussions Growth Characteristics}

The lettuce in the experiment prior to harvesting is shown in figure 4 while figure 5 shows the height of crops randomly selected from each treatment. 


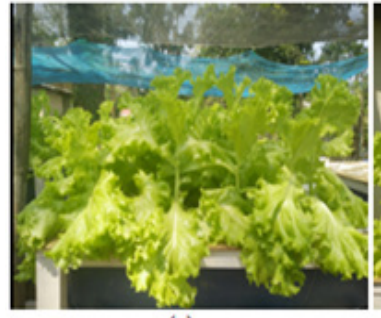

(a)

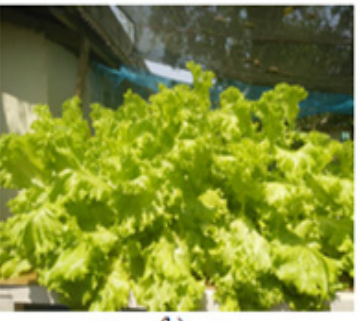

(b)

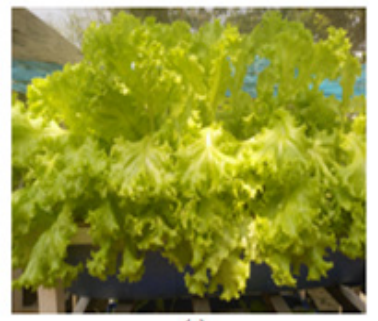

(c)

Figure 4. Photographs showing the experiment prior to the final harvest (a) To (control), (b) T1 (4 magnets), and (c) $T_{2}$ (6 magnets)

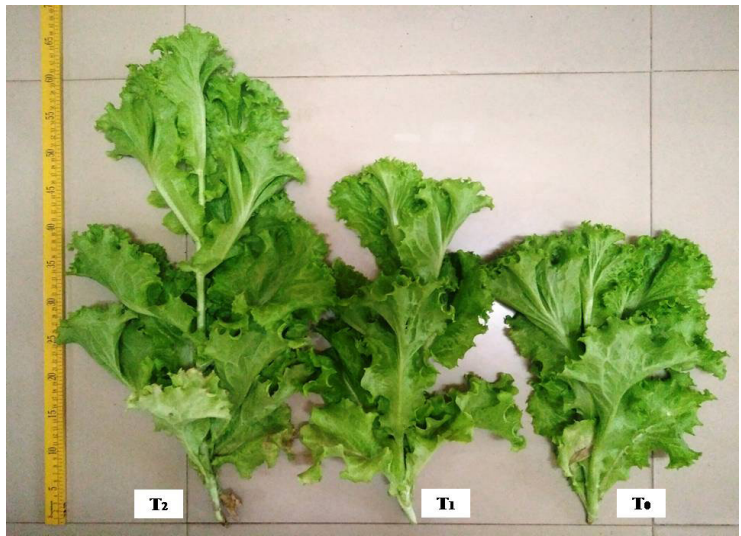

Figure 5. A photograph comparing the heights of representative crops from the three treatments

The weekly heights of lettuce grown in hydroponic system in response to the utilization of magnetically-treated irrigation water for twentyeight (28) days are presented in Figure 6. Results revealed that irrigation using magnetically treated water increased the height of the lettuce. Seven days after transplanting (7 DAT), the height of lettuce irrigated with water magnetized with six magnets was found to be significantly higher by 10. $66 \%$ than the height of lettuce irrigated with magnetized water using four magnets and the control, whereas, the height of lettuce irrigated with water treated with four magnets was found to be comparable with the height of lettuce in control. The height of lettuce irrigated with water magnetically treated with six magnets remained significantly higher $(p<0.01)$ than the heights of lettuce irrigated with water magnetized with four magnets and the control, but significant difference was observed between the heights of lettuce irrigated with water treated with four magnets and the control after 14 DAT. This trend was observed continuously until the harvest at 28 DAT. The result of the present study revealed that the magnetized water positively affects the growth of lettuce in hydroponic system as manifested by the significant increase in height. It also showed that the height of the crop increased with the increase in the number of magnets present in the magnetic device. This result could be due to the effects of the magnets on the water when magnetized as explained by different literatures. The structural arrays of water would be modified when magnetized resulting to an increase in the intercellular movement. Magnetic treatment changes hydrogen bonding and increased mobility of ions in water solution and thus resulted to reduction in EC, TDS and increase $\mathrm{pH}$ of solutions (Surendran et al., 2016). This permits to restore a structure of natural and enhanced water in its capability to disband and transport minerals (Hachicha et al., 2018) resulting to more nutrients absorbed in the water (Grewal \& Maheshwari, 2011; Mohamed \& Ebead, 2013; Eitken \& Turan, 2004). This process may result in higher nutrient uptake, increasing the physiological processes in crop production (Scaloppi, 2008). These changes 
might activate the hormones and enzymes faster during growth process which may result in an improved mobilization and transportation of nutrients and brought out biological activity in plants and consequently influence plants resulting to an improved growth and yield (Maheshwari \& Grewal, 2009; Surendran et al., 2016).

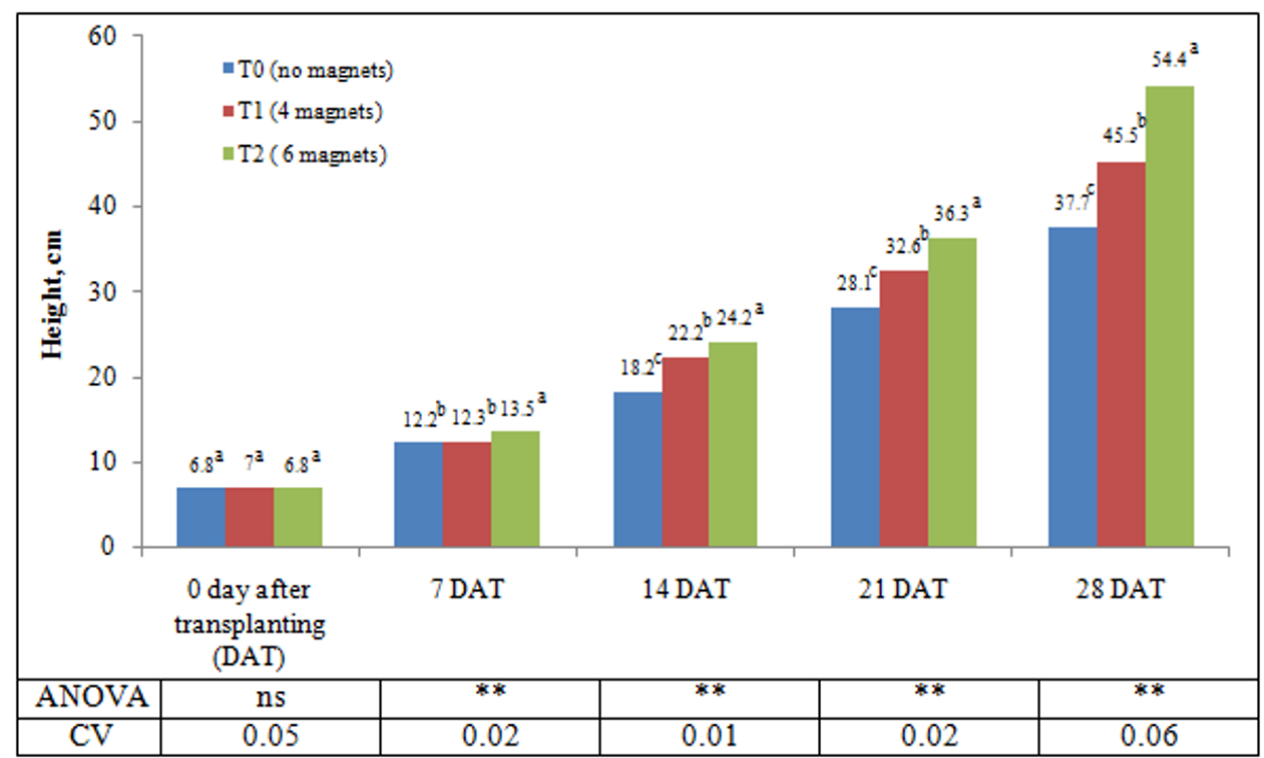

Note: Treatment means in a column that carries the same letter superscript are not significantly different based on the least significance difference (LSD) test at a 1\% level of probability.

Figure 6. Weekly heights $(\mathrm{cm})$ of lettuce as affected by magnetically treated water

This result of using magnetized water on the plant height of the test crop used in the present study is parallel but better $(44.30 \%$ higher vs. control) than the results of Amira, Qodos, and Hozayn (2010) which reported that the height common flax irrigated with magnetized water increased by $6.01 \%$ compared to the control. Hozayn, Abdallha, Abd El-Monem, El-Saady, and Darwish (2016), observed a significant increase of $16.75 \%$ and $13.85 \%$ in the height of canola and wheat, respectively, after irrigating with magnetized water over the control. Several research studies have shown that plants heights increased significantly in response to magnetic field effect against the control (Yusuf \& Ogunlela, 2015; Hozayn et al., 2014; Gudigar, 2013; Selim, 2008; Aladjadjiyan, 2007).

Table 1. Percentage effect of using magnetically treated water on the growth parameters of lettuce

\begin{tabular}{lcc}
\hline Parameters & $\mathbf{T}_{\mathbf{1}}$ & $\mathbf{T}_{\mathbf{2}}$ \\
\hline Height $(\mathbf{c m})$ at harvest & 20.69 & 44.30 \\
Leaf area $\left(\mathbf{c m}^{\mathbf{2}}\right)$ & 80.93 & 199.93 \\
Fresh weight $\mathbf{( g )}$ & 14.58 & 50.72 \\
Root length $(\mathbf{c m})$ & 19.16 & 37.00 \\
\hline
\end{tabular}




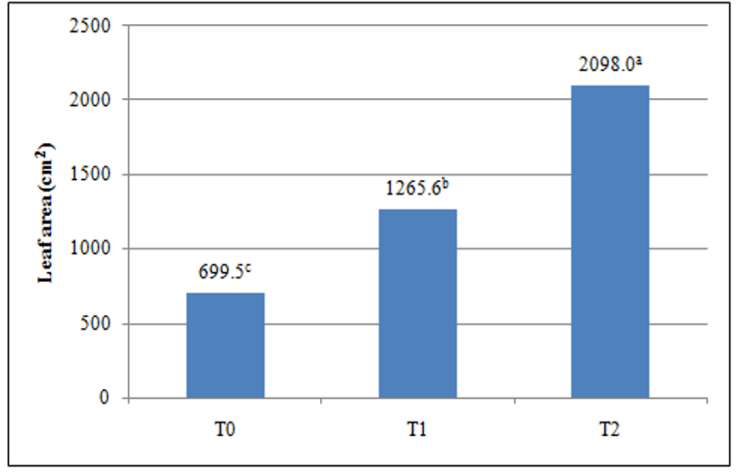

$T_{0}=$ control, $T_{1}=4$ magnets, $T_{2}=6$ magnets

Note: Treatment means in the figure that carries the same letter superscript are not significantly different based on the least significance difference (LSD) test at a $1 \%$ level of probability.

Figure 7. Leaf area $\left(\mathrm{cm}^{2}\right)$ of lettuce at harvest as affected by magnetically treated water

An important variable affecting light interception for photosynthesis and carbohydrate production is the leaf area in a canopy. The leaf areas of the lettuce grown in hydroponic system were significantly increased $(p<0.01)$ as results of applying irrigation with magnetically treated water, as shown in Figure 7. The leaf areas were found to be $1265.6 \mathrm{~cm}^{2}$ and $2098.0 \mathrm{~cm} 2$ for $T_{1}$ and $T_{2}$, respectively, whereas the control group recorded a leaf area of $699.5 \mathrm{~cm}^{2}$. The percentage increments in the leaf area were $80.93 \%$ and $199.93 \%$ for $\mathrm{T}_{1}$ and $T_{2}$, respectively against the leaf area of the control (Table 1). This result could be due to the effects of magnetization on the physical and chemical properties of water that positively affect the different crop growth parameters (Selim \& ElNady, 2011; Dagoberto, et al., 2002; Moon\& Chung, 2000; Pittman, 1977). The result conforms to those obtained by El-Yazied, Shalaby, Khalf and El-Satar (2011) that applying irrigation with magnetized water increases the leaf area of the plants. A parallel result was reported by (De Souza, 2005; Novitsky, 2001; \& Khattab, 2000) that magnetically treated water improves the leaf size of different seedlings.

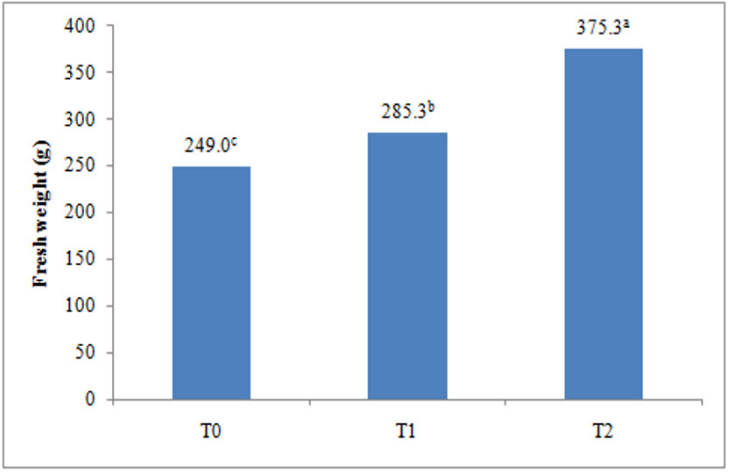

$T_{0}=$ control, $T_{1}=4$ magnets, $T_{2}=6$ magnets

Note: Treatment means in the figure that carries the same letter superscript are not significantly different based on the least significance difference (LSD) test at a 1\% level of probability.

Figure 8. Fresh weight (g) lettuce as affected by magnetically treated water

The fresh weights of lettuce grown in hydroponic system in response to the application of magnetically treated water as irrigation were increased significantly $(p<0.01)$ when compared to the control group, T0 (Figure 8). The fresh weights of the test crop were found to be $285.3 \mathrm{~g}$ (14.58\% higher than $\mathrm{T} 0), 375.3 \mathrm{~g}(50.72 \%$ higher than T0), respectively, for $T_{1}$ and $T_{2}$, whereas the control showed a fresh weight of $249.0 \mathrm{~g}$. Hozayn et al. (2016) reported a similar effect of magnetized water on the fresh weight of wheat. The fresh weight of wheat irrigated with magnetically treated water increased by $24.52 \%$ over the control. Recent studies concerning the effect of using magnetically treated irrigation likewise supported the results of the present research study, i.e., in turnip $22.76 \%$, $47.17 \%$ and $53.91 \%$, higher fresh weight with magnetically treated water (Haq et al., 2016). Similar significant effects have been recorded in the yield of snow pea and celery when applied magnetically treated irrigation water but under controlled environment conditions (Maheshwari \& Grewal, 2009). This result is consistent with the research works of Moussa, (2011), and De Souza, 
et al. (2006) which observed the effect of pretreatment of seeds with magnetized water as irrigation as the leaf, stem, and roots of tomato and bean significantly increased compared against the control. Further, magnetized water improves the fresh weight of different crops (Aladjadjiyan, 2002; Selim, 2008).

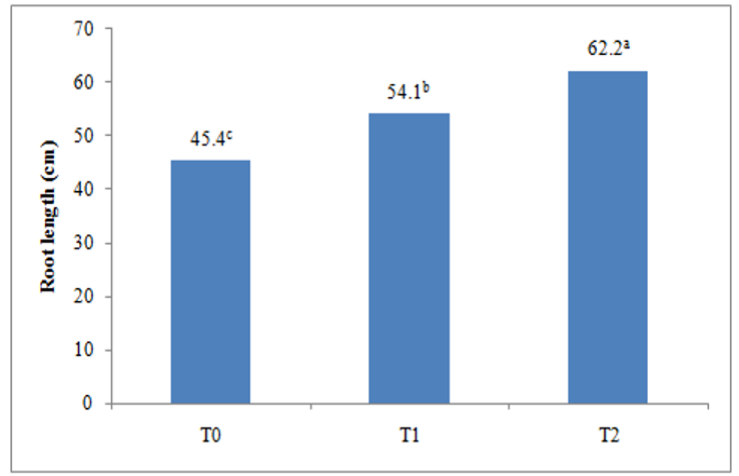

$T_{0}=$ control, $T_{1}=4$ magnets, $T_{2}=6$ magnets

Note: Treatment means in the figure that carries the same letter superscript are not significantly different based on the least significance difference (LSD) test at a $1 \%$ level of probability.

Figure 9. The length of roots $(\mathrm{cm})$ of lettuce as affected by magnetically treated water

The recorded lettuce root lengths were $45.4 \mathrm{~cm}$, $54.1 \mathrm{~cm}$ and $62.2 \mathrm{~cm}$ for $T_{0}, T_{1}$, and $T_{2}$, respectively as presented in Figure 9. The percentage increments in root lengths were $19.16 \%$ and $37.00 \%$ for $\mathrm{T} 1$ and T2, respectively, higher than the control (Table 1). This result could be due to the positive effects of magnets on the water when magnetized as manifested by better growth of crops. According to literatures, the changes in water when magnetized improved nutrient mobilization and consequently increased the physiological processes in crops. This improved root length enables the plants to effectively and efficiently absorb water and nutrients and consequently result in better yield.
This result coincides with the work of Haq et al., (2016) which revealed an increase in the root length of turnip from $6.20 \%-14.27 \%$ with an increasing magnetization dose of irrigation water. The root length of Triticum aestivum increased in response to magnetic irrigation water treatment. Several pieces of research have established the effectiveness of the magnetic field on the root growth of different plants (Belyavskaya, 2001 \& 2004; Cuartero \& Fernández-Muñoz, 1998; Muraji, 1992; Muraji, Asai, \& Tatebe, 1998). Positive effects of magnetized water on the growth of roots are significant as they seem to induce better capacity for water and nutrients uptake, providing more significant physical sustenance to the development of shoots. Improved growth and development of the roots could lead to improved root systems all throughout the lifespan of the plants (De Souza et al., 2006).

\subsection{Conclusion}

Based on the analysis of the single run experiment, the results of the present study established beneficial effects of using magnetically treated irrigation water on the growth parameters (height, leaf area, fresh weight, and root length) of lettuce grown in a hydroponic system. The magnetic treatment of water in the hydroponic system increased the height, leaf area, fresh weight, and root length of lettuce significantly. Utilization of the magnetic technology could enhance crop production with limited resources.

\section{Recommendation}

Since the technology is yet for more verification especially on field or macro application, the researchers recommend that more trials and replication be done.

\section{Acknowledgments}

The study was carried out with the technical 
assistance of the faculty of the college of engineering of the Cagayan State University at Sanchez Mira, Cagayan.

\section{References}

Agrawal, P \& Jacob, S (2010). Technologies for increased crop yield. ISTA. Cologne, Germany.

Aladjadjiyan, A. (2002). Study of the influence of the magnetic field on some biological characteristics of Zea maize. Journal of Central European Agriculture, 3 (2). 89-94.

Aladjadjiyan, A. (2007). The use of physical methods for plant growth stimulation in Bulgaria. Journal of Central European Agriculture, 8(3), 369-380.

Alatorre-Cobos, F., Calderon-Vazquez, C.\& IbarraLaclette, E., Young, L., Perez-Torres, C., Oropeza-Aburto, A., Mendez-Bravo, A., Gonzales-Morales, S., Gutierrez Alanis, D., Chacon, A., Pena-Ocana, B., \& Herrera-Estrella, L.(2014). An improved, low-cost, hydroponic system for growing Arabidopsis and other plant species under aseptic conditions. BMC Plant Biology. 14. 69. 10.1186/1471-2229-1469.

Ali, Y, \& Samaneh, R. (2017). Effects of magnetic treatment of irrigation water on the quality of soil: A comprehensive review, Indi American Journal of Pharmaceutical Sciences. 4(05), 1125-1129. Retrieved from http://www.iajps. com Accessed: October 2019.

Amira, M. S., Qados, A., \& Hozayn M. (2010). The response of growth, yield, yield components, and some chemical constituents of flax for irrigation with magnetized and tap water.
World Applied Science Journal, 8(5), 630-634.

Barman, N., Hasan, M., Islam, M.,\&Banu, N. (2016, July). A review of present status and future perspective of hydroponics technique. Plant Environment Development, 5(2), 1-7. Retrieved from http://www.botanyru.org/journal Accessed: September 2018.

Belyavskaya, N. (2001).Ultrastructure and calcium balance in meristem cells of pea roots exposed to extremely low magnetic fields. Advances in Space Research, 28(4), 645-650.

Belyavskaya, N. (2004). Biological effects due to a weak magnetic field on plants. Advances in Space Research, 34(7), 1566-1574.

Briones, R, Antonio, E, Habito, C, Porio E \&Songco D. (2017). Food security and nutrition in the Philippines: Strategic Review: Brain Trust Inc. http://docs.wtf.org/api/documents WFP-0000015508/download/. Accessed September 2018.

Castañeda, O, Patiño, M, Patiño, J, Aleman, R \& Torres, O. (2016) Effect of electric field on the kinetics of growth of lettuce (Lactuca sativa) in a hydroponic system. Journal of Agricultural Chemistry and Environment, 5, 113-120. 10.4236/jacen.2016.53013. Retrieved from http://www.scrip.org/journal/jacenhttp:// dx.doi.org/10.4236/jacen.2016.53013. September 2018.

Chang, K.T. and Weng, C.I. (2008). An investigation into structure of aqueous $\mathrm{NaCl}$ electrolyte solutions under magnetic fields.Computational Materials Science. 43. 1048-1055. 10.1016/j. commatsci.2008.02.020 
Cuartero, J. and R. Fernández-Muñoz, (1998).Tomato and salinity. Scientia Horticulturae, 78(1), 83125.

Dagoberto, G.F., Angel, D.S.T.,\& Lilita, S.P. (2002). Effect of magnetic treatment of onion (Allium сера) seeds on the germination and growth of seedlings. Alimentaria, 39 (337), 181-186.

De Souza, A. (2005). Pre-sowing magnetic treatment of tomato seeds: Effects on the growth and yield of plants cultivated late in the season. Spanish Journal of Agricultural Research, 3(1), 113-122.

De Souza, A., Garci, D., Sueiro L., Gilart, F., Porras, E.,\& Licea L. (2006). Presowing magnetic treatments of tomato seeds the growth and yield of plants. Bioelectromagnetics. 2(7), 247257

Dunn, B. (2013), Hydroponics. Technical Report. Retrieved from http://www.researchgate.net/ publication/280235408.Accessed: September 2018.

Eitken, A. \& Turan, M. (2004) Alternating magnetic field effects on yield and plant nutrient element composition of strawberry (Fragaria $\mathrm{x}$ ananassa cv. Camarosa). ActaAgriculturaeScandinavica, Section B-Soil \& Plant Science, 54(3), 135-139.

El-Yazid, A., Shalaby, A., Khalf SM. \&El-Satar A. (2011). Effect of magnetic field on seed germination and transplant growth of tomato. Journal of American Science, 7(12), 306-323.

Food and Agriculture Organization. (2009). 'How to feed the world in 2050', Food and Agriculture Organization of the United Nations, paper prepared for 'How to feed the world in 2050': High-level expert forum, 12-13 October 2009, Rome. Retrieved from http://www.fao. org/fileadmin/templates/wsfs/docs/expert_ paper/How_to_Feed_the_World_in_2050. Pdf. Accessed: October 2018.

Ferguson, S., Saliga III, R, \& Omay, S. (2014). Investigating the effects of hydroponic media on quality of greenhouse grown leafy greens. International Journal of Agricultural Extension, 02(03), 227-234. Retrieved from http://www.escijournals.net/IJAE. Accessed: November 2018

Gabriel, A.G. \& Mangahas, T.L.S. (2017). Indigenous people's contribution to the mitigation of climate variation, their perception, and organizing strategy for sustainable community based forest resources management in Caraballo Mountain, Philippines. Open Journal of Ecology, 7, 85100. Retrieved from https://doi.org/10.4236/ oje.2017.72007. Accessed: October 2018.

Gashgari, R., Alharbi, K., Mughrbil, K., Jan, A., \& Glolam A. (2018). Comparison between growing plants in hydroponic system and soil-based system. Proceedings of the 4th World Congress on Mechanical, Chemical and Material Engineering (MCM'18), Madrid, Spain, August 16-18, 2018. Paper No. ICMIE131.http://doi:1011159/icmie18.131. Accessed: October 2018

Grewal, H.S., and Maheshwari, B.L. (2011). Magnetic treatment of irrigation water and snow pea and chickpea seeds enhances early growth and nutrient contents of seedlings. Bioelectromagnetics, 32(1), 58-65. 
Gudigar, A. H. (2013). Effect of magnetic treatment on irrigation water quality, soil properties and growth of sunflower crop. Masters Thesis. Accessed: November 2017

Hachicha, M., Kahlaoui, B., Khamassi, N. Misle,\& Jouzdan, E. (2018) Effect of electromagnetic treatment of saline water on soil and crops. Journal of the Saudi Society of Agricultural Science 17, 154 - 162. Retrieved from www. ksu.edu.sa and www.sciencedirect.com. September 2018

Haq, Z., lqbal, M., Jamil, Y., Anwar, H., Younis, A., Arif, M., Fareed, Z., \&Hussain, F. (2016). Magnetically treated water irrigation effect on turnip seed germination, seedling growth, and enzymatic activities. Information Processing in Agriculture. 3 (2), 99-106. Retrieved from www.sciencedirect.com and www.elsevier. com/locate/inpa. Accessed: October 2018.

Hilal M.H., \&Hilal M.M. (2000). Application of magnetic technologies in desert agriculture: Seed germination and seedling emergence of some crops in a saline calcareous soil. Egypt Journal of Soil Science, 40(3), 413-423.

Hozayn, M. \& Amir Mohamed Saeed Abdul Qados (2010). Irrigation with magnetized water enhances growth, chemical constituent and yield of chickpea (Cicer arietinum L.). Agriculture and Biology Journal of North America, 1(4), 671-676. Retrieved from https:// scihub.org/ABJNA Accessed: October 2017.

Hozayn, M., Abd El Monem, A., Abd El-Fatah Elwia, T., \& El-Shatar, M.(2014). Future of magnetic agriculture in Arid and Semi-Arid regions (case study). Scientific Papers. Series A. Agronomy, Vol. LVII, 2014. Retrieved from http://agronomyjournal.usamv.ro/pdf/2014/ art35.pdf. Accessed: October 2018.

Hozayn, M, Abdallha, M.M., Abd El-Monem A.A., ElSaady, A.A.\&Darwish M.A. (2016). Applications of magnetic technology in agriculture: $A$ novel tool for improving crop productivity (1): Canola. African Journal of Agricultural Research, 11(5), pp. 441-449. Retrieved from: http://www.academicjournals.org/AJAR Accessed: October 2017.

Iqbal J., Cecil F., Ahmad K., Iqbal M., Mushtaq M., Naeem M.(2013). Kinetic study of $\mathrm{Cr}(\mathrm{III})$ and $\mathrm{Cr}(\mathrm{VI})$ biosorption using Rosa Damascenaphytomass: a rose waste biomass. Asian J Chem, 25, 2099-103.

Khattab, M. (2000). Pre-treatment of gladiolus cormels to produce commercial yield: I-effects of GA3, seawater and magnetic system on the growth and corms production. Alexandria Journal of Agricultural Research, 45(3), 181-1199.

Linehan, V., Thorpe, S., Andrews, N., Kim, Y.,\&Beaini, F. (2012). Food demand to 2050: Opportunities for Australian agriculture, ABARES conference Canberra, March. Retrieved from http:// daff.gov.au/abares/publications.Accessed: September 2018

Maheshwari, B.L.,\& Grewal, H.S. (2009). Magnetic treatment of irrigation water: Its effects on vegetable crop yield and water productivity. Agricultural Water Management. 96, 12291236. Retrieved from www.elsevier.com/ locate/agwat. Accessed: July 2019

Majid A. (2009). Effect of seed pre-treatment by magnetic fields on seed germination and 
ontogeny growth of agricultural plants. Islamic Azad University, Tehran, Iran.

Mohamed, A.I., \& Ebead, B.M. (2013) Effect of magnetic treated irrigation water on salt removal from a sandy soil and on the availability of certain nutrients. International Journal of Engineering, 2(2), 2305-8269. Retrieved from http://eaas-journal.org/survey/ userfiles/files/agriculture\%20engineering\%20 4(4).pdf. Accessed October 2019.

Moon, J.D.,\& Chung, H.S., (2000) Acceleration of germination of tomato seed by applying AC electric and magnetic fields. J. Electrostatic. 4(8), 103-114.

Mostafazadeh-Fard, B., Khoshravesh M., MousaviS, F., \& Kiani A.R. (2011). Effects of magnetized water and irrigation water salinity on soil moisture distribution in trickle irrigation. Journal of Irrigation and Drainage Engineering, 137(6), 398-403.

Moussa H.R. (2011). The impact of magnetic water application for improving common bean (Phaseolus vulgaris I.) production. New York Science Journal, 4(6), 15-20.

Muraji, M. (1992).Effect of alternating magnetic field on the growth of the primary root of corn. Magnetics, IEEE Transactions On, 28(4), 1996-2000.

Muraji, M., T. Asai, and W. Tatebe, (1998). The primary root growth rate of Zea mays seedlings grown in an alternating magnetic field of different frequencies. Bioelectrochemistry and Bioenergetics, 44(2), 271-273.

Murphy, M., Zhang, F., Nakamura, Y., andOmaye, S.
(2011). Comparison between hydroponically and conventionally and organically grown lettuces for taste, odor visual quality and texture: A pilot study. Food and Nutrition Sciences, 2, 124-127. Retrieved from DOI:104236/ fns.2011.22017 http://www.scirp.org/journal/ fns. Accessed: October 2018

Novitsky, Y.I. (2001). Growth of green onions in a weak permanent magnetic field. Russian Journal of Plant Physiology, 48(6), 709-716.

Pascual, M.P., Lorenzo, G.A., \& Gabriel, A.G. (2018). Vertical farming using hydroponic system: Toward a sustainable onion production in Nueva Ecija, Philippines. Open Journal of Ecology, 8, 25-41.https://doi.org/10.4236/ oje.2018.81003. October 2018.

Patil, A.G., (2014) Device for magnetic treatment of irrigation water and its effects on the quality and yield of banana plants. International Journal of Biological Science Applied 1, 152-156.

Pittman, U.J., (1977). Effect of magnetic seed treatment on yields of barley, wheat, and oats in southern Alberta. Canadian Journal of Plant Science, 57, 37-45.

Sace, C.F., and Estigoy, J.H. (2015). Lettuce production in a recirculating hydroponic system. American Journal of Agricultural Science, 2(5), 196-202. Retrieved from http:// www.aascit.org/journal/ajas. Accessed November 2019

Sace, C.F. \& Natividad, Jr., E.P. (2015). Economic analysis of an urban vertical garden for hydroponic production of lettuce (Lactuca sativa). International Journal of Contemporary Applied Sciences, 2 (7)7, 2015. Retrieved from 
http://www.ijcas.net. Accessed: November 2019

Sardare, M. \& Admane, S. (2013). A review on pants without soil - hydroponics. IJRET. 2(3), 299304. Retrieved from http://www.ijret.org/. October 2018.

Scaloppi, E.J. (2008). Irrigation of horticultural crops with magnetized water. The central theme, technology for all: sharing the knowledge for development. Proceedings of the International Conference of Agricultural Engineering, XXXVII Brazilian Congress of Agricultural Engineering, International Livestock Environment Symposium - ILES VIII, Iguassu Falls City, Brazil, 31st August to 4th September. : unpaginated

Selim, M. (2008).Application of magnetic technologies in correcting underground brackish water for irrigation in the arid and semi-arid ecosystem. The 3rd International Conference on water resources and arid environments, and the 1st Arab water forum. King Saud University, Riyadh, Saudi Arabia. http://www.icwrae-psipw.org/images/ stories/2008/Environment/6.pdf

Selim, A.F., El-Nady, M.F. (2011).Physio-anatomical responses of drought-stressed tomato plants to the magnetic field. Acta Astron. 69, 387396.

Shukla, S., Wagh, S., Vaishamapayan, V., Gaopande, M., \& Vishnoi S. (2016). Magnetic field effect on plant growth in hydroponic farming Journal of Basic and Applied Research International, 19 (4), 259-262. Retrieved from www.ikpress.org. Accessed: November 2019. treatment of wheat seeds (Triticum aestivum) as a growth stimulating technique Alimentaria, 39(337), 167-170.

Surendran, U., Sandeep, O., \&Joseph, E.J., (2016). The impacts of magnetic treatment of irrigation water on the plant, water, and soil characteristics. Agricultural Water Management, 178, 21-29.

Turker, M., Temerci, C., Battal, P., \&Erez, M. E. (2007). The effect of an artificial and static magnetic field on plant growth, chlorophyll and phytohormone levels in maize and sunflower plants. Phyton Ann. Rei. Bot, 46, 271-284.

United Nations. (2017). "World population projected to reach 9.8 billion in 2050, and 11.2 billion in 2100," United Nations, 21 June 2017. Retrieved from https://www.un.org/ development/desa/en/news/population/ world-population-prospects-2 $017 . \mathrm{h} \mathrm{t} \mathrm{m} \mathrm{I.}$ Accessed: September 2018.

Yusuf, K.O., \& Ogunlela A.O. (2015). Impact of magnetic treatment of irrigation water on the growth and yield of a tomato.Notulae Scientia Biologicae. 7(3), 345-348. DOI: 10.15835/nsb.7.3.9532 Retrieved from www. notlaebiologicae.ro. Accessed: July 2019. 